\title{
Pengaruh Perilaku Masyarakat dan Kondisi Lingkungan Terhadap Kejadian Demam Berdarah Dengue
}

\section{The Influence of Community Behaviour and Environmental Conditions to Dengue Hemorrhagic Fever}

\author{
Jasrida Yunita, Mitra, Herlina Susmaneli
}

\section{Program Studi Magister Ilmu Kesehatan Masyarakat STIKes Hang Tuah Pekanbaru}

\begin{abstract}
ABSTRAK
Data Dinas Kesehatan Kota Pekanbaru menunjukkan bahwa jumlah kasus DBD meningkat dua kali lipat dibandingkan Tahun 2010. Tiga kasus DBD tertinggi di Kota Pekanbaru, salah satunya berada pada kecamatan Tampan. Penelitian ini bertujuan untuk membuktikan pengaruh perilaku masyarakat dan kondisi lingkungan dengan kejadian Demam Berdarah Dengue. Metode penelitian dengan desain Kasus Kontrol yang dilaksanakan pada bulan September-Desember 2011 di wilayah kerja Puskesmas Sidomulyo Kota Pekanbaru. Jumlah sampel 224 terdiri dari 56 kasus dan 168 kontrol. Alat ukur yang digunakan adalah kuesioner. Analisis data untuk bivariat dengan uji Chi-Square dan multivariat dengan uji Regresi Logistik Ganda. Hasil penelitian menunjukkan untuk faktor Perilaku Masyarakat yang dominan berhubungan dengan kejadian DBD adalah variabel Kebiasaan menggantung pakaian, $\mathrm{OR}=6,29$ (95\% CI: 3,09-12,81) dan faktor Kondisi lingkungan yang dominan berhubungan dengan kejadian DBD adalah variabel Keberadaan jentik pada tempat penampungan air, OR=6,35 $(\mathrm{CI} 95 \%=2,66-15,12)$. Diharapkan pihak Puskesmas lebih mengintensifkan kegiatan pemeriksaan jentik berkala, masyarakat untuk lebih memperhatikan kegiatan $3 \mathrm{M}$ plus dan pelaksanaan PSN-DBD secara mandiri dan teratur serta memperhatikan perilaku menggantung pakaian.
\end{abstract}

Kata kunci: Demam Berdarah Dengue, perilaku masyarakat, kondisi lingkungan

\section{ABSTRACT}

Pekanbaru City Health Department data show that the number of dengue cases has doubled compared to 2010. The three highest dengue cases in the city of Pekanbaru, one of which was at Tampan sub distric. This study aims to prove the influence of people's behavior and environmental conditions with the incidence of dengue hemorrhagic fever. The case study method to design controls are carried out from September to December 2011 in the working area of the City Health Center Charming Pekanbaru. Number of samples consisted of 56224 cases and 168 controls. Measuring instrument used was questionnaire. Data for bivariate analysis with Chi-Square test and multivariate test Multiple Logistic Regression. The results showed for Community Behavioral dominant factor associated with the incidence of DHF is a variable habit of hanging clothes with $O R=6.29$ (95\% CI: 3.09 to 12.81) and environmental conditions are dominant factors related to the incidence of dengue is the presence of variable larvae in the water penambungan place with $O R=6.35(C 195 \%=2.66$ to 15.12$)$. The health center is expected to further intensify the activities of larvae periodic inspection, the community to pay more attention to activities plus $3 M$ and the implementation of PSN-DBD independently and regularly and observe the behavior of hanging clothes.

Keywords: Dengue Hemorrhagic Fever, Community behavior, environmental conditions

\section{PENDAHULUAN}

Penyakit Demam Berdarah Dengue (DBD) adalah penyakit yang disebabkan oleh virus dengue dan ditularkan oleh nyamuk Aedes Aegypti. Di Indonesia, Kejadian Luar Biasa (KLB) demam berdarah hampir terjadi setiap tahun dan biasanya terjadi pada musim penghujan, namun sejak awal tahun 2011 ini sampai bulan Agustus 2011 tercatat jumlah kasus relative menurun (Kementerian Kesehatan RI, 2011). Program pencegahan dan pemberantasan DBD telah berlangsung lebih kurang 43 tahun dan berhasil menurunkan angka kematian dari 41,3\% pada tahun 1968 menjadi $0,87 \%$ pada tahun 2010 , tetapi belum berhasil menurunkan angka kesakitan. Jumlah penderita cenderung meningkat, penyebarannya semakin luas, menyerang tidak hanya anak-anak tetapi juga golongan umur yang lebih tua. Pada tahun 2011 sampai bulan Agustus tercatat 24.362 kasus dengan 196 kematian (CFR: 0,80\%) (Kementrian Kesehatan RI,2011). 
Di Provinsi Riau mengalami peningkatan kasus DBD sebanyak 1.897 kasus ( $\mathrm{IR}=42,2$ per 100.000 penduduk) pada tahun 2005 dan mengalami penurunan kasus pada tahun 2006 sampai 2008 hingga $50 \%$. Tahun 2006 berjumlah 948 kasus ( $\mathrm{IR}=21,3$ per 100.000 penduduk), tahun 2007 berjumlah 759 kasus ( $\mathrm{IR}=17,6$ per 100.000 penduduk), dan pada tahun 2008 berjumlah 680 kasus (IR=15,8 per 100.000 penduduk).

Selama tahun 2007 jika dibandingkan dengan jumlah kasus tahun 2006, kasus DBD di Propinsi Riau mengalami peningkatan pada awal-awal tahun yaitu pada bulan Januari sampai dengan Mei dan mengalami penurunan jumlah kasus pada bulan-bulan berikutnya yaitu bulan Juni sampai Desember (Dinkes Provinsi Riau, 2008). Jumlah Kasus DBD di Kota Pekanbaru berjumlah 202 kasus (Profil Dinas Kesehatan Kota Pekanbaru, 2010). Berdasarkan data Dinas Kesehatan Kota Pekanbaru Tahun 2011 menunjukkan bahwa jumlah kasus DBD meningkat hamper 2 kali lipat dibandingkan Tahun 2010. Tiga Kecamatan tertinggi, salah satunya berada di Kecamatan Tampan.

Meningkatnya jumlah kasus DBD dalam tiga tahun terakhir di Kota Pekanbaru kemungkinan disebabkan karena adanya pemukiman baru, lokasi rumah berdekatan dengan aliran limbah rumah tangga dan ada juga lokasi rumah yang terlalu berdekatan, kurangnya perilaku masyarakat terhadap pembersihan sarang nyamuk, perilaku masyarakat yang masih membuang sampah sembarangan serta kurangnya peran serta masyarakat dalam pelaksanaan Pemberantasan Sarang Nyamuk (PSN). Sehingga dapat digambarkan bahwa perilaku masyarakat kurang memperhatikan kebersihan lingkungan dan belum melakukan pencegahan serta pemberantasan sarang nyamuk (PSN-DBD) dengan mengendalikan nyamuk vektor Aedes Aegypti.

Penyebaran dan tinggi rendahnya angka kesakitan demam berdarah dipengaruhi oleh beberapa faktor diantaranya tinggi rendahnya populasi vektor, virulensi virus, imunitas penduduk, kepadatan penduduk, mobilitas penderita dan kemampuan virus memperbanyak diri dalam tubuh nyamuk serta perilaku manusia yang dapat memberi peluang tempat

perkembangbiakan nyamuk. Hal ini terbukti bahwa tinggi rendahnya populasi vektor memegang peranan penting pada kejadian meningkatnya populasi aedes aegypti sebagai penular penyakit demam berdarah yang berlangsung pada musim hujan (Depkes RI, 1994)

Tujuan penelitian ini adalah untuk membuktikan pengaruh perilaku masyarakat dan kondisi lingkungan dengan kejadian demam berdarah dengue di Kecamatan Tampan Kota Pekanbaru.

\section{METODE}

Jenis penelitian ini adalah Kuantitatif Analitik Observasional dengan desain penelitian Kasus Kontrol yang dilaksanakan mulai bulan September sampai dengan bulan Desember 2011 di wilayah kerja Puskesmas Sidomulyo Kecamatan Tampan Kota Pekanbaru. Jumlah sampel dalam penelitian ini sebanyak 224 yang terdiri dari 56 kasus dan 168 kontrol. Jenis data yang dikumpulkan adalah data sekunder yaitu kasus Demam Berdarah Dengue yang diambil dari rekam medik di Puskesmas Sidomulyo sedangkan kontrol adalah tetangga dari kasus. Selain data sekunder, data primer dikumpulkan dari semua variabel independen. Pengumpulan data primer dilakukan dengan wawancara terstruktur baik kasus dan kontrol dengan menggunakan instrumen kuesioner. Untuk pemeriksaan keberadaan jentik nyamuk, dilakukan dengan mengobservasi tempat penampungan air, untuk melihat ada tidaknya jentik nyamuk. Analisis bivariat dilakukan dengan uji ChiSquare dan uji Regresi Logistik Ganda dengan Model Prediksi untuk analisis Multivariat.

\section{HASIL}

Hasil uji bivariat terhadap 7 variabel, terdapat 3 variabel yang mempunyai hubungan signifikan dengan kejadian DBD yaitu Frekuensi Menguras Tempat Penampungan Air (pvalue $=0,040)$, Kebiasaan Menggantung Pakaian (pvalue $=0,001$ ) dan Keberadaan Jentik Pada Tempat Penampungan Air (pvalue $=0,001$ ). Sedangkan variabel Menutup Penampungan Air, Kebiasaan Menimbun Barang Bekas serta Penggunaan Pelindung tidak bermakna secara statistik. Berdasarkan nilai OR maka masyarakat yang mempunyai kebiasaan jarang menguras bak penampungan air lebih berisiko 1,98 kali untuk menderita DBD dibandingkan dengan masyarakat yang sering menguras penampungan air $(95 \%$ CI 1,08-3,67). Masyarakat yang biasa menggantung pakaian berisiko 4,5 kali untuk menderita DBD dibandingkan dengan masyarakat yang tidak biasa menggantung pakaian serta masyarakat yang disekitar lingkungan rumahnya ditemui cukup banyak jentik pada tempat penampung air beresiko 4,2 kali menderita DBD dibanding dengan tidak ada/ sedikit jentik di dalam tempat penampung air (lihat tabel 1).

Hasil analisis multivariat dapat disimpulkan bahwa variabel yang berhubungan secara bermakna dengan penyakit DBD adalah Kebiasaan Menggantung Pakaian dan Keberadaan Jentik pada Tempat Penampung Air. Hasil analisis didapatkan bahwa variabel yang paling dominan berhubungan dengan kejadian DBD adalah Keberadaan Jentik pada Tempat Penampung air dengan nilai $\mathrm{OR}=6,35$ artinya masyarakat yang disekitar rumahnya terdapat banyak 
jentik nyamuk, lebih beresiko untuk menderita DBD 6,35 kali dibandingkan dengan mereka yang disekitar rumahnya sedikit jentik setelah dikontrol dengan variabel Kebiasaan Menggantung Pakaian (95\% CI : 3,09-12,8) (lihat tabel 2).

Tabel 1.

Faktor-faktor yang Berhubungan dengan Kejadian DBD

\begin{tabular}{|c|c|c|c|c|c|c|c|c|c|}
\hline \multirow{3}{*}{ No } & \multirow{3}{*}{ Variabel } & \multicolumn{4}{|c|}{ Kasus dan Kontrol } & \multirow{2}{*}{\multicolumn{2}{|c|}{ Total }} & \multirow{3}{*}{$\begin{array}{c}\text { OR } \\
(95 \% \mathrm{CI})\end{array}$} & \multirow{3}{*}{$P$ Value } \\
\hline & & \multicolumn{2}{|c|}{ Kasus } & \multicolumn{2}{|c|}{ Kontrol } & & & & \\
\hline & & $\mathbf{n}$ & $\%$ & $\mathbf{n}$ & $\%$ & $\mathbf{N}$ & $\%$ & & \\
\hline \multirow[t]{4}{*}{1} & Frekuensi Menguras Penampung Air & & & & & & & & \\
\hline & Jarang & 29 & 51,8 & 59 & 35,1 & 88 & 39,3 & $1,98(1,08-3,67)$ & 0,040 \\
\hline & Sering & 27 & 48,2 & 109 & 64,9 & 136 & 60,7 & & \\
\hline & Total & 56 & 100 & 168 & 100 & 224 & 100 & & \\
\hline \multirow[t]{4}{*}{2} & $\begin{array}{l}\text { Kebiasaan Menutup } \\
\text { Penampung Air }\end{array}$ & & & & & & & & \\
\hline & Tidak Menutup & 23 & 41,1 & 66 & 39,3 & 89 & 39,7 & $1,08(0,58-1,99)$ & 0,937 \\
\hline & Menutup & 33 & 58,9 & 102 & 60,7 & 135 & 60,3 & & \\
\hline & Total & 56 & 100 & 168 & 100 & 224 & 100 & & \\
\hline \multirow[t]{4}{*}{3} & Kebiasaan Menimbun Barang Bekas & & & & & & & & \\
\hline & Tidak Menimbun & 49 & 87,5 & 126 & 75.0 & 175 & 78,1 & $2,33(0,98-5,55)$ & 0,076 \\
\hline & Menimbun & 7 & 12,5 & 42 & 25.0 & 49 & 21,9 & & \\
\hline & Total & 56 & 100 & 168 & 100 & 224 & 100 & & \\
\hline \multirow[t]{4}{*}{4} & Kebiasaan Menggantung Pakaian & & & & & & & & \\
\hline & Tidak Biasa & 16 & 28,6 & 108 & 64,3 & 124 & 55,4 & $4,50(2,33-8,71)$ & 0,001 \\
\hline & Biasa & 40 & 71,4 & 60 & 35,7 & 100 & 44,6 & & \\
\hline & $\begin{array}{l}\text { Total } \\
\text { Penggunaan Pelindung }\end{array}$ & 56 & 100 & 168 & 100 & 224 & 100 & & \\
\hline 5 & $\begin{array}{l}\text { Tidak Menggunakan } \\
\text { Menggunakan }\end{array}$ & $\begin{array}{r}53 \\
3\end{array}$ & $\begin{array}{c}94,6 \\
5,4\end{array}$ & $\begin{array}{r}162 \\
6\end{array}$ & $\begin{array}{c}96,4 \\
3,6\end{array}$ & $\begin{array}{r}215 \\
9\end{array}$ & $\begin{array}{r}96,0 \\
4,0\end{array}$ & $0,65(0,16-2,71)$ & 0,844 \\
\hline \multirow[t]{4}{*}{6} & $\begin{array}{l}\text { Total } \\
\text { Keberadaan Jentik padaTempat } \\
\text { Penampung Air }\end{array}$ & 56 & 100 & 168 & 100 & 224 & 100 & & \\
\hline & Banyak Jentik & 48 & 85,7 & 99 & 58,9 & 147 & 65,6 & $4,18(1,86-9,39)$ & 0,001 \\
\hline & Tidak Ada/Sedikit Jentik & 8 & 14,3 & 69 & 41,1 & 77 & 34,4 & & \\
\hline & $\begin{array}{l}\text { Total } \\
\text { Kepadatan Rumah }\end{array}$ & 56 & 100 & 168 & 100 & 224 & 100 & & \\
\hline \multirow{3}{*}{7} & Padat & 45 & 80,4 & 129 & 76,8 & 174 & 77,7 & $1,24(0,58-2,62)$ & 0,711 \\
\hline & Tidak Padat & 11 & 19,6 & 39 & 23,2 & 50 & 22,3 & & \\
\hline & Total & 56 & 100 & 168 & 100 & 224 & 100 & & \\
\hline
\end{tabular}

Tabel 2.

Permodelan Multivariat Tahap Akhir

\begin{tabular}{lcrrrrrrr}
\hline \multicolumn{1}{c}{ Variabel } & \multirow{2}{*}{ B } & \multirow{2}{*}{ S.E } & Wald & Df & P value & OR & 95\% C.I \\
\hline Kebiasaan Menggantung Pakaian & 1.839 & .363 & 25.661 & 1 & 0.000 & 6.288 & 3.087 & 12.806 \\
Keberadaan Jentik pada Tempat Penampung Air & 1.848 & 0.443 & 17.424 & 1 & 0.000 & 6.345 & 2.665 & 15.108 \\
\hline
\end{tabular}




\section{PEMBAHASAN}

\section{Faktor Perilaku Masyarakat yang Berhubungan dengan Kejadian DBD}

Variabel dari Faktor Perilaku Masyarakat yang paling dominan berhubungan dengan DBD adalah variabel Kebiasaan Menggantung Pakaian. Masyarakat yang mempunyai kebiasaan mengantung pakaian di rumahnya mempunyai resiko 6,29 kali lebih besar untuk terkena DBD dibandingkan dengan mereka yang tidak biasa menggantung pakaian $(95 \%$ CI : 3,09-12,81). Pakaian yang manggantung dalam ruangan merupakan tempat yang disenangi nyamuk Aedes aegypti untuk beristirahat setelah menghisap darah manusia. Setelah beristirahat pada saatnya akan menghisap darah manusia kembali sampai nyamuk tersebut cukup darah untuk pematangan sel telurnya. Jika nyamuk yang beristirahat pada pakaian menggantung tersebut menghisap darah penderita demam berdarah dan selanjutnya pindah dan menghisap darah orang yang sehat maka dapat tertular virus demam berdarah dengue (Widodo, 2002).

Penelitian ini sesuai dengan penelitian yang dilakukan oleh Sukowinarsih \& Cahyati (2010), Supratikmiasih (2005) dan Widyastuti (2004), bahwa kebiasaan menggantung pakaian ada hubungan dengan kejadian DBD. Untuk itu maka diperlukan peran dari petugas kesehatan untuk melakukan penyuluhan khususnya mengenai resiko DBD bila masyarakat biasa mengandung pakaian dirumahnya.

\section{Faktor Lingkungan yang Berhubungan dengan Kejadian DBD}

Variabel yang paling dominan berhubungan dengan Kejadian DBD adalah Keberadaan jentik pada penampung air $(\mathrm{p}=0,001)$. Kekuatan hubungan antara keberadaan jentik aedes aegypti dengan kejadian DBD adalah sebesar 6,35 (CI 95\%= 2,66-15,12) artinya masyarakat yang disekitar rumahnya ada jentik nyamuk/aedes aegypti pada penampung air lebih berisiko 6,35 kali untuk menderita DBD dibanding dengan masyarakat yang disekitar rumahnya tidak ada jentik nyamuk/ aedes aegypti pada penampung air.

Keberadaan jentik nyamuk yang hidup sangat memungkinkan terjadinya demam berdarah dengue. Jentik nyamuk yang hidup di berbagai tempat seperti bak air, atau hinggap di lubang pohon, lubang batu, pelepah daun, tempurung kelapa, pelepah pisang, potongan bambu (Depkes RI, 2002). Virus dengue ini memiliki masa inkubasi yang tidak terlalu lama yaitu antara 3-7 hari, virus akan terdapat di dalam tubuh manusia (Sutaryo, 2005). Oleh kerena itu apabila keberadaan jentik nyamuk dibiarkan maka yang terjadi adalah kejadian demam berdarah dengue yang akan terus meningkat

Sama dengan hasil yang diteliti oleh Wati (2009) mengenai kejadian DBD dengan keberadaan jentik Aedes aegypti pada kontainer menunjukkan bahwa nilai $\mathrm{p}=0,001$. Dengan demikian dapat disimpulkan faktor keberadaan jentik Aedes aegypti pada kontainer mempunyai hubungan terhadap kejadian DBD di Kelurahan Ploso Kecamatan Pacitan.

Hasil penelitian ini diperkuat dengan penelitian Sumekar (2007). Dalam penelitiannya tentang faktor-faktor yang berhubungan dengan keberadaan jentik nyamuk Aedes di Kelurahan Raja Basa. Hasil penelitiannya menyatakan bahwa jentik Aedes di Kelurahan Raja Basa ada hubungan dengan kejadian DBD.

Berbeda dengan penelitian yang dilakukan oleh Fathi, dkk (2005), hasil penelitiannya menunjukkan bahwa pada 4 kelurahan dengan KLB penyakit DBD didapatkan ABJ dengan kepadatan tinggi (>95\%), sedangkan pada daerah kontrol didapatkan 12 kelurahan mempunyai $\mathrm{ABJ}$ dengan kepadatan tinggi dan sisanya 4 kelurahan mempunyai ABJ dengan kepadatan rendah $(<95 \%)$.

Peran serta petugas kesehatan diperlukan untuk membiasakan masyarakat untuk menutup tempat penampungan air, menimbun barang-barang bekas, untuk menghindari jentik nyamuk. Pada saat ini dikenal istilah " $3 \mathrm{M}$ plus" yaitu kegiatan $3 \mathrm{M}$ yang diperluas. Bila PSN DBD dilaksanakan oleh seluruh masyarakat, maka populasi nyamuk aedes aegepty dapat ditekan serendah-rendahnya.

\section{Faktor Perilaku Masyarakat yang Tidak Berhubungan dengan Kejadian DBD} Frekuensi Menguras Tempat Penampungan air Analisis multivariat, menunjukkan bahwa tidak ada hubungan yang signifikan frekuensi menguras tempat penampungan air dengan kejadian DBD. Hal ini kemungkinan disebabkan karena adanya bias informasi dalam pengkategorian frekuensi pengurasan.

\section{Kebiasaan Menutup Tempat Penampung Air}

Hasil penelitian ini menunjukkan tidak ada hubungan yang signifikan antara kebiasaan menutup tempat penampung air dengan penyakit DBD $(p=0,937)$. Tidak adanya hubungan kebiasaan menutup tempat penampungan air pada penelitian ini, karena masyarakat yang mempunyai kebiasaan tidak menutup tempat penampungan air, baik pada kasus dan kontrol tidak menunjukkan perbedaan persentase dalam kejadian DBD. Pada kasus ditemui sebesar 42,1\% mereka yang tidak biasa menutup tempat penampungan air, sedangkan pada kontrol ditemui sebesar 39,3\%. Hasil penelitian ini tidak sejalan dengan penelitian yang dilakukan oleh Arsin dan Wahiduddin (2004) tentang faktor-faktor yang berpengaruh terhadap kejadian demam berdarah dengue (DBD) di Kota Makasar. 


\section{Kebiasaan Menimbun Barang Bekas}

Berdasarkan analisis multivariat diperoleh nilai $\mathrm{p}=0,163$, artinya tidak ada hubungan antara kebiasaan menimbun barang bekas dengan kejadian DBD. Tidak ditemuinya hubungan antara kebiasaan menimbun barang bekas dengan kejadian DBD pada penelitian ini kemungkinan disebabkan karena adanya data yang homogen, yaitu pada kelompok kasus, dimana hanya ditemui sebesar $12,5 \%$ masyarakat yang mempunyai kebiasaan menimnbun barang bekas. Penelitian ini tidak sejalan dengan penelitian yang dilakukan olehWati (2009).

\section{Penggunaan Pelindung dari Gigitan Nyamuk}

Hasil penelitian menunjukkan bahwa tidak ada hubungan antara penggunaan pelindung dengan Kejadian DBD $(\mathrm{p}=0,617)$. Hal ini disebabkan karena variabel penggunaan pelindung merupakan variabel yang homogen, dimana hanya $4 \%$ masyarakat yang menggunakan pelindung dari gigitan nyamuk, seperti penggunaan kelambu, memakai obat nyamuk atau pemakaian lotion anti nyamuk. Hasil pada penelitian ini tidak sejalan dengan penelitian yang dilakukan oleh Wati di Wilayah Kerja Puskesmas Cempiring Kabupaten Kendal tahun 2009.

\section{Faktor Kondisi Lingkungan yang Tidak berhubungan dengan Kejadian DBD}

Variabel kondisi lingkungan yang tidak berhubungan dengan kejadian DBD adalah kepadatan rumah. Hasil penelitian ini diperoleh nilai $\mathrm{p}=0,711$, artinya tidak ada hubungan yang signifikan antara Kepadatan rumah dengan Kejadian DBD. Jarak antar rumah pada wilayah kerja Puskesmas Sidomulyo sebagian besar $(77,7 \%)$ memiliki jarak rumah yang rapat ( $\leq 5 \mathrm{~m}$ dengan tetangga sebelahnya). Kontrol diambil dari tetangga kasus, sehingga kondisi lingkungan tidak dapat diketahui pengaruhnya pada penelitian ini. Hasil penelitian ini tidak sesuai dengan penelitian yang dilakukan oleh Roose (2008) di Kecamatan Bukit Raya Kota Pekanbaru.

\section{KESIMPULAN}

Faktor Perilaku Masyarakat yang dominan berhubungan dengan kejadian DBD adalah variabel Kebiasaan menggantung pakaian dengan nilai $\mathrm{OR}=6,0$ (95\% CI: 2,89-12,62), artinya mereka yang mempunyai kebiasaan mengantung pakaian di rumahnya mempunyai resiko 6,0 kali lebih besar untuk terkena DBD dibandingkan dengan mereka yang tidak biasa menggantung pakaian. Faktor Kondisi lingkungan yang dominan berhubungan dengan kejadian DBD adalah variabel Keberadaan jentik pada tempat penambungan air dengan $\mathrm{OR}=$ sebesar $6,1(\mathrm{CI}$ $95 \%=2,53-14,67)$ artinya mereka yang dirumahnya ada jentik nyamuk pada penampung airnya berisiko 6,1 kali untuk menderita DBD dibanding dengan mereka yang dirumahnya tidak ada jentik nyamuk pada penampung airnya.

\section{SARAN}

Diharapkan pihak Puskesmas lebih mengintensifkan kegiatan pemeriksaan jentik berkala, serta bagi masyarakat untuk lebih memperhatikan kegiatan 3M plus dan pelaksanaan PSN-DBD secara mandiri dan teratur dan masyarakat harus lebih memperhatikan perilaku kebiasaan menggantung pakaian, karena nyamuk itu menyukai benda yang menggatung seperti pakaian.

\section{UCAPAN TERIMA KASIH}

Ucapan terima kasih ditujukan kepada Kopertis Wilayah X yang telah membiayai penelitian ini, kepada Pimpinan dan masyarakat di Wilayah Kerja Puskesmas Sidomulyo Kecamatan Tampan tempat penelitian ini dilakukan.

\section{DAFTAR PUSTAKA}

Depkes RI, (1994). Nyamuk Penular DBD. Ditjen $P P M$ dan PLP. Jakarta

Depkes RI, (2005). Pencegahan dan Pemberantasan Demam Berdarah Dengue DiIndonesia. Jakarta

Dinkes Kota Pekanbaru (2010). Profil Dinkes Kota Pekanbaru, Pekanbaru

Fathi, dkk. (2005). Peran Faktor Lingkungan dan Perilaku terhadap Penularan Demam Berdarah Dengue di Kota Mataram. Jurnal Kesehatan Lingkungan. Vol. 2. No. 1. Juli 2005: 1-10

Kementrian Kesehatan RI, 2011. Subdirektorat Pengendalian Arbovirosis - Dit PPBB -Ditjen PP dan PL, [on-line] : www.pppl.depkes.go.id/ .../INFORMASI U MUM DBD 2011.pdf. Akses : 28 September 2011

Roose, A. (2008). Hubungan Sosiodemografi dan Lingkungan dengan Kejadian Penyakit Demam Berdarah Dengue (DBD) di Kecamatan Bukit Raya Kota Pekanbaru. Tesis. Universitas Sumatra Utara. Medan

Riau Pos (2011). Marpoyan Damai Tertinggi DBD, Kamis 24 November 2011

Sumekar DW. (2007). Faktor-Faktor yang Berhubungan dengan Keberadaan Jentik Nyamuk Aedes di Kelurahan RajaBasa. Seminar Hasil Penelitian dan Pengabdian kepada Masyarakat. Unila. 
Sutaryo. (2005). Dengue. Yogyakarta: Medika FK UGM

Wati,WE. (2009). Beberapa Faktor yang Berhubungan dengan Kejadian Demam Berdarah Dengue (DBD) di Kelurahan Ploso Kecamatan Pacitan Tahun 2009. Skripsi : Universitas Muhammadiyah Surakarta.
Widyana. (1998). Faktor-faktor yang Mempengaruhi Kejadian DBD di Kabupaten Bantul. Jurnal Epidemiologi Indonesia. Vol. 2 Edisi 11998:7.

Widyastuti P. (ed). 2005. Epidemiologi Suatu Pengantar, edisi 2. Jakarta: EGC 